UDC 636.4.87.7/8

(C) 2016

O. Kotliar, candidate of agricultural sciences

Institute of Animal Science NAAS, Kharkiv

\title{
COMPARISON OF EFFICIENCY OF EFFECT OF SALINE AND CHELATED FORMS OF MN AND ZN IN FEEDING PIGS
}

The purpose. To compare efficiency of effect of saline, chelated and combihumate forms of feed additives $\mathrm{Mn}$ and $\mathrm{Zn}$ upon indexes of body height and reproduction of repair sows. Methods. Decrease of levels of compensation of deficiency of $\mathrm{Mn}$ and $\mathrm{Zn}$ in basic ration (BR) in the chelated form for 50 or 25\%, in combi-humate - up to $25 \%$ of the level for saline form. Results. According to effect on indexes of body height it is possible to decrease levels of compensation for chelates in 4 times for $\mathrm{Mn}$ and in 2 times for $\mathrm{Zn}$, to effect on indexes of reproduction - in 2 times for Mn, while for Zn decrease does not justify itself; for combi-humates of Mn and Zn decrease of levels of compensation to 25\% justifies itself. Conclusions. Combi-humates of Mn and Zn exceed by efficiency effect of saline and chelated forms at more low levels of compensation of their deficiency in BR.

Key words: feeding of repair sows, Mn, Zn, salts, chelates, humates.

Manganese and zinc impact on growth and puberty of pigs and their reproductive performance during the first period of gestating and suction, but the with the usage of salt forms much of it is spent unproductively in the body, which increases the costs to them and their allocation in the composition of waste. The replacing of salt forms of trace elements in chelated micronutrients reduces unproductive element usage in animals, and the efficiency of chelated forms in small doses can be preserved or even increased. The disadvantage of chelated forms, ligands of which are amino acids or organic acids, is the ability of ligand to quickly react with metabolic substances after dissociation, then they can not serve as the ligand and delay the minerals in the body for a long time. For 
Magnesium and Zinc is important at the period of late puberty and during the first hunting period when you want to create a reserve of deposited elements in the body of pigs in quantities that allow to plan rations for gestation and suction breeding pigs and during the first farrowing to reduce the content of micronutrients in their diets. The alternative to Chelates is a combination of salt forms of trace elements with a humic (combyhumates) in feed additives humates (combyhumats) [1-2], whereby ions of humates with the help of antioxidant qualities capable of supporting divalent $\mathrm{Mn}$ in optimum condition . Use of humate food additives in the feeding of agricultural animals and poultry had been observed in works [3-9].

The purpose of the study. The comparison of the effectiveness of the salt, chelate forms of feed additives in $\mathrm{Mn}$ and $\mathrm{Zn}$ on the growth of pigs and on reproductive performance of sows at first farrowing.

Materials and methods of research. Two experiments were conducted on large white breed pigs at the age of 6-9 months on « Breeding Plant of 20 anniversary of October" the preliminary period lasted 1 month. (5-6 months of pigs' life). To determine the effect of "aftereffects" of all forms of micronutrient supplements after completing of its giving to pigs were examined the average daily growth of pigs per 1 month. (9-10 months of pigs' life), three months of research + one month of "Aftereffects" made a cycle of giving micro elemenents.

The scheme of the experiment comparing to the effectiveness of the various forms of Mn: 1 group. (Negative control) - ration (R) without additives of Mn, Mn deficient at about 50\% of the existing "Rules ..." [10]; 2 group (Control) - R + 100\% Mn deficiency on account of salt form; 3 group - $\mathrm{R}+100 \%$ Mn deficiency due to chelate of Mn; Group 4 (research) $-\mathrm{R}+50 \%$ Mn deficiency due to chelate Mn; Group $5-\mathrm{R}+20 \% \mathrm{Mn}$ deficiency due to chelate Mn; Group 6 - R + 20\% Mn deficiency on account of salt form $+0.25 \mathrm{~g}$ of sodium humate / $\mathrm{kg}$ of feed. By the age of 7.5 months pigs were first inseminated, they were further inseminated in the time of hunting signs in pigs analog with sperm of the same boars-sires; the same insemination scheme was performed in the following experiment (with Zn). From 9 months age up to the end of the suction of pigs and their piglets have not received any supplements in addition to $\mathrm{R}$ and dry feed 
respectively. The scheme of the experiment was similar to Zn, R zinc deficiency in made up 55\% for pigs of the current "norm ...".

Supplements were made as part of premix based on main feed, the dose of $5 \%$ from the weight of feed, Group 1 received in both experiments the same amount of feed without Mn or Zn. Salt forms are represented by sulfates, chelate - riboflavin predecessor complexes (here and next RP) on the carrier with zeolite powder, the content of trace elements in both chelates - $15.0 \mathrm{~g} / \mathrm{kg}$, the manufacturer - "Kronos-Agro". Prices of both chelates $50.0 \mathrm{UAH}$. / Kg.

The experimental results are shown in table 1.

Manganese. The replacement of $100 \%$ compensation deficit salt form into $100 \%$ compensation chelated form has not led to the likely increase in the average live mass (hereinafter ALM) of pigs after all terms of giving supplements and did not affected ALM after a period of "aftereffect"; no significant difference was observed in daily increments during the first month of research period, average daily gain tended to increase up to $46.1 \mathrm{~g}(\mathrm{P}<0.10)$, but decreased for the second month to $41.0 \mathrm{~g}(8.3 \%, \mathrm{P}<$ $0.05)$ per cycle - had the tendency to increase up to $15.8 \mathrm{~g}(3.3 \%, \mathrm{P}<0.10)$. The cost of 1 $\mathrm{kg}$ increase of living mass (LM) during the research period increased to $14.12 \mathrm{UAH}$, per cycle at $13.81 \mathrm{UAH}$, profitability decreased respectively to 2.6 and $1.8 \%$. In pig-breeding and in sucking period: probable cost reduction of feed / kg of increase to 1.12 MJ ME pigs (further $\mathrm{ME})(6.1 \%, \mathrm{P}<0.01)$, the tendency to increase the average daily gain for the period of suction to $113 \mathrm{~g},(4.4 \%, \mathrm{P}<0.10)$ and the increase of the average live weight of pigs at the age of 21 -day to $0.23 \mathrm{~kg}(3.5 \%, \mathrm{P}<0.10)$ and 60 -day to $0.67 \mathrm{~kg}(4.1 \%$, $\mathrm{P}<0.10$ ). The cost of 1 quintal of LM decreased to 63.11 UAH. (4.9\%), profitability increased to $6.2 \%$.

The replacement of $100 \%$ deficit compensation of Mn according to salt forms to $50 \%$ of chelate compensation in feeding pigs: during the first month of research period the gain is at the same level, during the second - declined to $44.2 \mathrm{~g}(9.0 \%, \mathrm{P}<0.05)$, for the third month and the period of "aftereffect" - increased to $14.7 \mathrm{~g}$ (3.4\%) and $10.0 \mathrm{~g}$ (2.2\%) for the entire cycle they barely increased. According to the effect on the growth, this level of compensation Mn deficiency can be competitive compared to the salt form only for 
short term use (1-2 months). For ALM of pigs throughout the cycle, this group is somewhat behind the previous one on economic indicators - very similar to it. The period of farrowing and sucking: this level of compensation has probable advantages according to ALM of piglets at birth $-17 \mathrm{~g}(1.4 \%, \mathrm{P}<0.05)$ at the age of 21 -days - at $0.35 \mathrm{~kg}(5.3 \%$, $\mathrm{P}<0.001)$ at the age of 60 -days - at $0.87 \mathrm{~kg}(5.3 \%, \mathrm{P}<0.01)$ average daily gain $-14.5 \mathrm{~g}$ (5.6\%, $\mathrm{P}<0.001)$, average costs of feed / kg gain - $123 \mathrm{MJ}(8.3 \%, \mathrm{P}<0.001)$ the tendency of reduction of average age of the first insemination to 4.98 days $(1.6 \%, \mathrm{P}<0.10)$, the average number of insemination / fertilization 0.37 times $(15.9 \%, \mathrm{P}<0.10)$ the increase of the average number of fetuses / farrowing at 0.50 fetuses (5.0\%, $\mathrm{P}<0.10)$, although up the age of the first insemination and the average number of insemination / farrowing had tendency to lag behind the previous group. The cost of 1 quintal of ALM declined to 106.48 UAH. (8.1\%), profitability increased to $10.8 \%$. The level of compensation of 50\% of Mn deficiency is the most competitive according to the studies.

The replacement of $100 \% \mathrm{Mn}$ compensation deficit by salt forms of $25 \%$ compensation chelated form for feeding pigs: the first month of research period had a tendency to lag the increase of gains to $46.1 \mathrm{~g}(8.8 \%, \mathrm{P}<0.10)$ (at end of the first month ALM reduced to $2.23 \mathrm{~kg}$, or $2.4 \%, \mathrm{P}<0.05$ ) in the second month the gains were virtually identical, the third - increased gains in $29.2 \mathrm{~g}(14.7 \%, \mathrm{P}<0.01)$ at the end of this cycle, the level of compensation did not yield a salt form of ALM pigs and economic indicators. The farrowing and sucking period: the tendency to increasing ALM of pigs in 21- and 60days age respectively at $0.25 \mathrm{~kg}(3.8 \%, \mathrm{P}<0.10)$ and $0.58(3.5 \%, \mathrm{P}<0.10)$, an increased average daily gain of $9.8 \mathrm{~g}(3.8 \%, \mathrm{P}<0.10)$, likely reduction of the cost of feed / $\mathrm{kg}$ of increase to $1.20 \mathrm{MJ}(6.5 \%, \mathrm{P}<0.01)$, the reduction of the cost of 1 quintal of $\mathrm{LM}$ to 53.0 UAH., the increase of profitability to $5.2 \%$, which is less than the previous group.

The replacement of $100 \%$ Mn compensation deficit by salt forms of $25 \%$ compensation combyhumate of Mn for feeding pigs: the tendency to increase the average daily gain was only during the second month research period to $37.5 \mathrm{~g}(7.6 \%, \mathrm{P}<0.10)$ for the third month, the difference increases to $77.2 \mathrm{~g}(18.0 \%, \mathrm{P}<0.001)$ for the period of increments increased to $42.6 \mathrm{~g}(8.9 \%, \mathrm{P}<0.01)$, per cycle - $35.6 \mathrm{~g}(7.5 \%, \mathrm{P}<0.001)$. ALM of pigs at the end of the research period and cycle increases, respectively, to $3.22 \mathrm{~kg}$ 
(2.7\%, $\mathrm{P}<0.05$ ) and $3.56 \mathrm{~kg}$ (for $2.7 \%, \mathrm{P}<0.05$ ). The cost of 1 quintal ALM at end of the research period and cycle decreased respectively to 3.39 and to 22.58 UAH., profitability increased to $4.5 \%$. The period of farrowing and sucking: increasing in ALM of piglets at birth up to $18 \mathrm{~g}(1.5 \%, \mathrm{P}<0.05)$ at the age of 21-day - to $0.27 \mathrm{~kg}(4.1 \%, \mathrm{P}<0.05)$ at the age of 60 -days - to $0.97 \mathrm{~kg}(5.9 \%, \mathrm{P}<0.001)$, average daily gain - to $16.1 \mathrm{~g}(6.2 \%$, $\mathrm{P}<0.001)$, increasing in ALM slot at the age of 60-days to $14.28 \mathrm{~kg}(9.3 \%, \mathrm{P}<0.001)$, average milk yield of sows up to $5.56 \mathrm{~kg}(9.8 \%, \mathrm{P}<0.01)$, lower average feed cost $/ \mathrm{kg}$ of increase to $1,23 \mathrm{MJ}(6.7 \%, \mathrm{P}<0.001)$ has the tendency to increase the average number of fetuses / farrowing to 0.64 fetuses $(6.4 \%, \mathrm{P}<0.10)$ and ALM of newborn nest to $0.54 \mathrm{~kg}$ (for 3.5\%, P <0.10), reducing the cost of 1 quintal of ALM for $110.38 \mathrm{UAH}$. (8.4\%) and increasing the profitability to $11.3 \%$. Combyhumate of $\mathrm{Mn}$ is a competitive substitute for salt and chelate forms of $\mathrm{Mn}$, more able to positively influence the growth and reproductive performance, than four times greater dose of salt and twice as high chelate dose form.

Zinc. The replacement of $100 \%$ compensation of Zn deficiency by salt form of $100 \%$ compensation deficit due to the chelate form in a feeding pigs led to an increase in average daily gain of only during the period of "aftereffect" in $28.1 \mathrm{~g}(6.1 \%, \mathrm{P}<010)$; not significant difference in ALM of pigs after all terms of giving supplements and the period of "aftereffect" were observed ; except for downward trend of feed costs / kg of increase during the "aftereffect" to $3.91 \mathrm{MJ}(5.8 \%, \mathrm{P}<0.10)$ significant difference in the cost of feed / kg gain were observed. The cost of 1 quintal of ALM rate rose to 18.60 UAH. (2.6\%), profitability decreased to $3,4 \%$. The period of farrowing and sucking: has a tendency to downward the number of weak piglets / farrow to 0.39 heads. (2.1 times, $\mathrm{P}<0.10)$, an increase in preservation of piglets in 60 days age to $5.1 \%(\mathrm{P}<0.05)$ and ALM of piglets at the age of 21-day to $0.22 \mathrm{~kg}(3.2 \%, \mathrm{P}<0.05)$, lowering of feed costs / $\mathrm{kg}$ of increase to $0.70 \mathrm{MJ}(5.5 \%, \mathrm{P}<0.001)$. With a relatively high price of $\mathrm{Zn}$ chelate and high need for compensation Zn deficiency economic indicators have improved a little: the cost of $1 \mathrm{~kg}$ of ALM nest fell to $3.50 \mathrm{UAH}$. (10.7\%), profitability increased to $0.37 \%$.

The replacement of $100 \% \mathrm{Zn}$ compensation deficit by salt form of $50 \%$ compensation in the form of chelates for feeding pigs: according to the ALM this group overtakes salt 
form until the end of the second month of research period and surpasses it for the third month (1.26 kg or 1, $0 \%$, not likely), even at the end of the period of "aftereffects" ALM increasing at $1.93 \mathrm{~kg}$ (3.4\%) was not likely; the likely increase in average daily gains were recorded in the second month of research period (47.8 g or 9.8\%, $\mathrm{P}<0.001$ ), during the "aftereffects" period (42.5 grams or 9.1\%, $\mathrm{P}<0.05$ ) for three months of research period ( $25.8 \mathrm{~g}$ or $5.3 \%, \mathrm{P}<0.05$ ) for the cycle - to $24.8 \mathrm{~g}$ or $5.3 \%, \mathrm{P}<0.01$ ). Average cost of feed / kg of increase give the likely reduction of costs in the second and third months of research for the entire period and the research period, respectively, $5.62 \mathrm{MJ}$ (8.9\%, $\mathrm{P}<0.001)$, to $5.46 \mathrm{MJ}(8.3 \%, \mathrm{P}<0.05)$ and $3.23 \mathrm{MJ}(5.1 \%, \mathrm{P}<0.05)$ the downward tendency for the period of aftereffect and cycle giving $3.43 \mathrm{MJ}(5.1 \%, \mathrm{P}<0.10)$ and 3.25 MJ respectively (5 , 1\%, $\mathrm{P}<0.10$ ). However, due to relatively high prices and relatively high chelate needs of zinc deficiency, the compensation cost of 1 quintal of ALM nest fell to $0.56 \mathrm{UAH}$., profitability increased to $0.1 \%$. The period of farrowing and sucking: decrease in the average number of weak piglets / farrow to 0.48 heads. (At 64.0\%, $\mathrm{P}<0.05)$ increase in pig-breeding ALM to $32 \mathrm{~g}(2.7 \%, \mathrm{P}<0.001)$ increase in the average preservation of piglets at the age of 60 days to $4.2 \%(\mathrm{P}<0.10)$ and decrease of average costs of feed / $\mathrm{kg}$ of increase to $0.41 \mathrm{MJ}(1.9 \%, \mathrm{P}<0.10)$; cost of 1 quintal of ALM of nests increased to $21.05 \mathrm{UAH}$. (1.7\%), profitability decreased to $2.17 \%$.

The replacement of $100 \%$ Zn compensation deficit by salt forms of $25 \%$ Zn deficiency compensation of chelate for feeding pigs: during the research period and the period of "aftereffects" ALM of pigs was lower at the end of the first month of research period - as a tendency (for $2.11 \mathrm{~kg}$ or $2.3 \%, \mathrm{P}<0.10$ ), further decreasing the gap. Average daily gain during the first months tended to lag behind to $26.7 \mathrm{~g}(5.3 \%, \mathrm{P}<0.10)$, in the second - did not significantly overwhelmed, only to $23.3 \mathrm{~g}$ (4.8\%), the third month had the tendency to increase up to $24.3 \mathrm{~g}(5.2 \%, \mathrm{P}<0.10)$, overall research period at almost the same level. Average cost of feed / kg of increase significantly decreased only in the third month of research period to $3.24 \mathrm{MJ}(4.9 \%, \mathrm{P}<0.10)$. The cost of 1 quintal of ALM increased to 6.12 UAH. (0.9\%), profitability decreased to 1,1\%. Pig-breeding and in sucking period: has a tendency to the average reduction of the age of the first insemination at 7.89 days (2.7\%, $\mathrm{P}<0.01)$, reducing the average number of piglets / farrows at the age of 21-days to 
0.70 heads (7.1\%), reduction of ALM of nest at birth, in 21- and 60-days age respectively to $0.75 \mathrm{~kg}$ (6.1\%), $3.41 \mathrm{~kg}(5.1 \%)$ and $7.69 \mathrm{~kg}$ (4.6\%), while reducing the average number of normally developed piglets / farrows to 0.80 heads. $(8.4 \%, \mathrm{P}<0.05)$ and feed cost / $\mathrm{kg}$ of increase to $0.49 \mathrm{MJ}(2.5 \%, \mathrm{P}<0.05)$. The cost of 1 quintal of ALM of nests increased to $87.21 \mathrm{UAH}$. (7.1\%), profitability fell to $8.54 \%$.

The replacement of $100 \% \mathrm{Zn}$ compensation deficit by $25 \% \mathrm{Zn}$ compensation of combyhumate for feeding pigs: the tendency to increasing in ALM of pigs at end of the third month of research period and a probable increase in the end of the period of "aftereffects" - to $2.17 \mathrm{~kg}(1.8 \%, \mathrm{P}<0.10)$ and $3.05 \mathrm{~kg}(2.3 \%, \mathrm{P}<0.05)$, the tendency of increasing average daily rate for the second month of research period to $27.1 \mathrm{~g}$ (5.5\%, $\mathrm{P}<0.10$ ), likely increase for the third month and during the "aftereffects" period pursuant to $46.8 \mathrm{~g}(10.0 \%, \mathrm{P}<0.001)$ and $32.6 \mathrm{~g}(8.1 \%, \mathrm{P}<0.05)$; during the giving period and period of gain rise to $32.0 \mathrm{~g}(6.6 \%, \mathrm{P}<0.01)$. Average consumption of food tended to decline in the second month of research period to $3.31 \mathrm{MJ}(5.3 \%, \mathrm{P}<0.10)$ in the third likely to fall to $5.96 \mathrm{MJ}(9.1 \%, \mathrm{P}<0.001)$, a total three months of research period - to 3.81 MJ (6.0\%, $\mathrm{P}<0.01)$ during the "aftereffects" - to $4.43 \mathrm{MJ}(6.6 \%, \mathrm{P}<0.05)$ for the cycle to $3.90 \mathrm{MJ}(6.0 \%, \mathrm{P}<0.05)$. The cost of 1 quintal of ALM decreased to 16.86 UAH. (2.4\%), profitability increased to $3.2 \%$. The sucking and pig-breeding period: the tendency to increase the ALM slot at the age of 60 -days to $6.72 \mathrm{~kg}(4.0 \%, \mathrm{P}<0.10)$ and ALM of pig during the pig-breeding to $21 \mathrm{~g}(1.8 \%, \mathrm{P}<0.10)$, probable reducing of costs of feed / $\mathrm{kg}$ of increase to $0.69 \mathrm{MJ}(3.5 \%, \mathrm{P}<0.01)$; all the other combyhumate indices are not inferior to salt forms, but there was no increase. The cost of 1 quintal of ALM of pigs decreased to 177.72 UAH. (12.9\%), profitability increased to $17.4 \%$. Zinc combyhumate is more efficient than salt and chelated form for the growth of pigs and reproductive performance during the first farrowing, with four time lower amount of Zinc, further introduced to balance rations. 


\begin{tabular}{|c|c|c|c|c|c|c|}
\hline Indices & Group 1 & Group 2 & Group 3 & Group 4 & Group 5 & Group 6 \\
\hline \multicolumn{7}{|c|}{ Manganese } \\
\hline ADI: $6-7$ months & $446,0 \pm 31,3$ & $522,5 \pm 16,9^{a}$ & $554,1 \pm 5,1^{\sigma}$ & $529,7 \pm 16,2^{a}$ & $476,4 \pm 12,5$ & $533,1 \pm 9,0^{\text {a }}$ \\
\hline - 7-8 months & $447,8 \pm 26,0$ & $492,1 \pm 15,9$ & $451,1 \pm 8,0$ & $447,9 \pm 6,7$ & $489,1 \pm 10,9$ & $529,6 \pm 9,8^{a}$ \\
\hline - 8-9 months & $447,4 \pm 21,1$ & $430,0 \pm 15,2$ & $463,9 \pm 14,0$ & $444,7 \pm 14,9$ & $493,4 \pm 12,9$ & $507,2 \pm 10,7^{\mathrm{a}}$ \\
\hline - 9-10 months & $458,6 \pm 10,3$ & $452,1 \pm 8,2$ & $469,7 \pm 12,9$ & $462,1 \pm 5,6$ & $465,5 \pm 6,5$ & $464,0 \pm 10,8$ \\
\hline Fertilization / farrow, times & $2,80 \pm 0,20$ & $2,33 \pm 0,17^{x}$ & $2,25 \pm 0,16^{\mathrm{a}}$ & $2,70 \pm 0,15$ & $2,38 \pm 0,18$ & $2,27 \pm 0,14^{\mathrm{a}}$ \\
\hline High fertilization, heads / farrow & $9,10 \pm 0,28$ & $9,89 \pm 0,26^{x}$ & $10,00 \pm 0,33^{x}$ & $10,20 \pm 0,20^{b}$ & $9,75 \pm 0,45$ & $10,18 \pm 0,12^{b}$ \\
\hline piglets / nest: - for 21 days & $8,80 \pm 0,25$ & $9,67 \pm 0,24^{\mathrm{a}}$ & $9,63 \pm 0,26^{\mathrm{a}}$ & $9,90 \pm 0,28^{b}$ & $9,38 \pm 0,32$ & $10,09 \pm 0,16^{\mathrm{c}}$ \\
\hline - on $60^{\text {th }}$ day (separation) & $8,70 \pm 0,21$ & $9,33 \pm 0,29^{x}$ & $9,50 \pm 0,53^{a}$ & $9,80 \pm 0,33^{a}$ & $9,38 \pm 0,32^{x}$ & $9,63 \pm 0,31$ \\
\hline ALM of piglets: at birth & $1,188 \pm 0,008$ & $1,190 \pm 0,007$ & $1,193 \pm 0,008$ & $1,207 \pm 0,006^{\mathrm{a}}$ & $1,193 \pm 0,008$ & $1,208 \pm 0,006^{\mathrm{a}}$ \\
\hline - 21days from birth & $6,59 \pm 0,11$ & $6,59 \pm 0,09$ & $6,82 \pm 0,11^{x}$ & $6,94 \pm 0,06^{\sigma}$ & $6,84 \pm 0,10^{x}$ & $6,86 \pm 0,09^{a}$ \\
\hline - 60 days from birth (separation) & $16,45 \pm 0,26$ & $16,46 \pm 0,26$ & $17,13 \pm 0,26^{x}$ & $17,33 \pm 0,17^{\mathrm{a}}$ & $17,04 \pm 0,26^{x}$ & $17,43 \pm 0,18^{b}$ \\
\hline Average daily increase, $\mathrm{g}$ & $258,7 \pm 4,4$ & $258,8 \pm 4,1$ & $270,1 \pm 4,3$ & $273,3 \pm 2,8^{b}$ & $268,6 \pm 4,3$ & $274,9 \pm 3,0^{c}$ \\
\hline \multicolumn{7}{|c|}{ Zinc } \\
\hline ADI: $6-7$ months & $436,7 \pm 16,1$ & $505,7 \pm 13,5^{b}$ & $512,0 \pm 12,9^{\mathrm{c}}$ & $491,0 \pm 18,0^{a}$ & $463,0 \pm 20,4$ & $526,7 \pm 6,7^{c}$ \\
\hline - 7-8 months & $448,4 \pm 8,9$ & $489,0 \pm 11,1^{\mathrm{c}}$ & $510,3 \pm 12,9^{c}$ & $536,8 \pm 4,9^{\mathrm{c}}$ & $512,3 \pm 11,3^{c}$ & $516,1 \pm 6,8^{\mathrm{c}}$ \\
\hline - 8-9 months & $456,3 \pm 13,3$ & $468,8 \pm 10,2$ & $480,0 \pm 12,1$ & $511,3 \pm 12,1^{b}$ & $493,1 \pm 6,9^{\mathrm{a}}$ & $515,6 \pm 5,3^{\mathrm{c}}$ \\
\hline - 9-10 months & $455,6 \pm 12,4$ & $460,0 \pm 10,7$ & $488,1 \pm 11,0^{x}$ & $484,8 \pm 7,8^{x}$ & $477,4 \pm 9,7$ & $492,6 \pm 10,0^{a}$ \\
\hline Fertilization / farrow, times & $2,60 \pm 0,27$ & $2,08 \pm 0,19$ & $2,27 \pm 0,21$ & $2,00 \pm 0,23^{x}$ & $2,33 \pm 0,17$ & $1,90 \pm 0,10^{\mathrm{a}}$ \\
\hline High fertilization, heads / farrow & $9,40 \pm 0,31$ & $10,33 \pm 0,33^{x}$ & $9,91 \pm 0,29$ & $9,91 \pm 0,25$ & $9,67 \pm 0,33$ & $10,50 \pm 0,33^{a}$ \\
\hline piglets / nest: - for 21 days & $9,00 \pm 0,30$ & $9,92 \pm 0,29^{\mathrm{a}}$ & $9,63 \pm 0,20^{x}$ & $9,63 \pm 0,19^{x}$ & $9,22 \pm 0,28$ & $10,00 \pm 0,21^{\mathrm{a}}$ \\
\hline - on $60^{\text {th }}$ day (separation) & $8,80 \pm 0,29$ & $9,33 \pm 0,20^{x}$ & $9,45 \pm 0,13^{a}$ & $9,36 \pm 0,20$ & $9,00 \pm 0,29$ & $9,70 \pm 0,21^{\mathrm{a}}$ \\
\hline ALM of piglets: at birth & $1,190 \pm 0,011$ & $1,196 \pm 0,009$ & $1,211 \pm 0,010^{x}$ & $1,228 \pm 0,008^{\mathrm{c}}$ & $1,201 \pm 0,011$ & $1,217 \pm 0,010^{\mathrm{a}}$ \\
\hline - 21days after birth & $6,75 \pm 0,09$ & $6,79 \pm 0,09$ & $7,01 \pm 0,07^{\mathrm{a}}$ & $6,92 \pm 0,07^{x}$ & $6,93 \pm 0,08^{x}$ & $6,94 \pm 0,09^{x}$ \\
\hline - 60 days from birth (separation) & $17,24 \pm 0,19$ & $17,85 \pm 0,15^{b}$ & $17,93 \pm 0,14^{b}$ & $17,67 \pm 0,13^{a}$ & $17,65 \pm 0,17^{x}$ & $17,87 \pm 0,15^{c}$ \\
\hline Average daily increase, $\mathrm{g}$ & $267,5 \pm 3,0$ & $277,6 \pm 2,4^{\mathrm{B}}$ & $278,7 \pm 2,3^{c}$ & $274,0 \pm 2,4^{\mathrm{a}}$ & $274,2 \pm 3,0^{x}$ & $277,6 \pm 2,3^{c}$ \\
\hline
\end{tabular}




\section{Conclusions}

1.The change of salt forms of $\mathrm{Mn}$ into chelate form in feeding pigs can reduce its quantity when balancing rations by half compared to the salt form with no decline in growth and positive impact on the growth; while reducing their number remains four times a positive impact on the growth, but not reproductive performance. For $\mathrm{Zn}$ reduction, its number doubled during the transition from salt to the form of chelate and justifies on the effect of the growth, but not on the reproductive performance.

2. The replacement of salt forms listed in micronutrients combination of salt form of humic feed additives (combyhumate) reduces the amount of $\mathrm{Mn}$ and $\mathrm{Zn}$ in balancing rations four times compared to the salt form, with the growth of pigs and reproductive performance during the first pig-breeding that surpass the figures of salt forms as well as chelates.

\section{Bibliography}

1. Жоробекова Ш. Ж. Макролигандные свойства гуминовых кислот. - Фрунзе: Илим. - 1987.

2. Котляр О. С. Ефективність дії сольових та хелатних мікроелементів у годівлі свиней / О. С. Котляр, В. О. Саприкін // Вісник аграрної науки. - 2014. - № 2. - C. 25-28.

3. Dobrzanski Z. Proekologiczne preparaty huminowe dla zwierat gospodarskich / Z. Dobrzanski // Zesz. Nauk. AR Wroc., Zootechnica. - 1999. - V. 39. - S. 41-48.

4. Chudola - Drozdowska B. Wplyw podawania cieletom wyciagu z wegla brunatnego oraz Acinormin Polfa na wskazniki rownowagi kwasowo-zasadowej krwi / B. Chudola - Drozdowska, W. Janeczek, G. Frackiewicz // Med. Vet. - 1993. - R. 49. - N. 7. - S. 329-331.

5. Chudola - Drozdowska B. Influence of brown coal, huminic acids and their mixture fed to calves on health and formation of chosen blood indexes / B. Chudola Drozdowska, W. Janeczek, R. Kupczynski // Vet. Med. Czech. - 2000. - V. 45. - N. 4. P. 116-117. 
6. Korniewicz A. Efectywnosc stosowania preparatow huminowych w zywieniu tucznikow / A. Korniewicz, Z. Dobrzanski, R. Kolacz, D. Korniewicz // Acta Scientiarum Polonorum. Zootechnica. - Bydgoszcz. - 2004. - R. 3. - N. 1. - S. 35-48.

7. Petryshak R. Influence of Humex preparation on growth and development of nonsuckling piglets and Probiodor on digestibility of mixtures for experimental on laboratory rats / R. Petryshak, Y. Pivtorak, K. Petkov e.a. // Folia Univ. Agriculturae Stetnensis Zootechn. - 2005. - N. 47. - P. 117-120.

8. Wplyw wegla brunatnego oraz kwasow huminowych na wyniki odchowu prosiat / S. Jasek, W. Poznanski, J. Nicpon e.a. //Med. Vet. - 1993. - N. 4. - S. 178 - 181.

9. Zastosowanie kompleksowych preparatow $\mathrm{z}$ wegla brunatnego $\mathrm{w}$ odchowie prosiat / W. Poznanski, S. Jasek, A. Rzasa e.a. // Zesz. Nauk. AR Wroc., Zootechnica. 1997. - N. 323. - S. 145-154.

10. Нормы и рационы кормления сельскохозяйственных животных. Справочное пособие. 3-е изд., перераб. и доп. / Под ред. А. П. Калашникова, В. И. Фисинина, В. В. Щеглова, Н. И. Клейменова. - М., 2003. - 456 с. 